BIOMEDICINE

\title{
Study of association between polymorphisms in the PSMB5 (rs11543947) and PSMA3 (rs2348071) genes and multiple sclerosis in Latvians
}

\author{
J. Kalnina ${ }^{1}$, N. Paramonova ${ }^{1}$, N. Sjakste ${ }^{2}$, T. Sjakste ${ }^{1}$ \\ ${ }^{1}$ Genomics and Bioinformatics, Institute of Biology of the University of Latvia, \\ 3, Miera Str., Salaspils, Latvia, LV-2169 \\ ${ }^{2}$ Latvian Institute of Organic Synthesis, \\ 21, Aizkraukles Str., Riga, Latvia, LV-1006 \\ tanja@email.lubi.edu.lv
}

\begin{abstract}
Functional realization of many signalling proteins and transcription factors implicated in the development and progression of multiple sclerosis is mediated by proteasomes. Aim of this case-control study was to evaluate genetic variations in the PSMB5 and PSMA3 genes encoding proteasomal subunits on the susceptibility to multiple sclerosis in Latvians. Methods. The rs11543947 (PSMB5) and rs2348071 (PSMA3) loci were genotyped in 291 multiple sclerosis patients and 305 healthy individuals and analysed general, subtype and sex-specific associations with the disease. Results. Loci rs 11543947 and rs2348071 were identified as disease neutral and susceptible respectively. The rs 2348071 heterozygous genotype GA showed strong main effect $(P<0.001 ;$ OR $=$ $=1.891,95 \% C I[1.360-2.628])$, and moderate $(P<0.01 ; O R=1.663,95 \% C I[1.152-2.402])$ and strong $(P<$ $<0.001 ; O R=2.459,95 \%$ CI [1.534-3.943]) association with relapsing-remitting and secondary progressive phases of disease respectively. No genotype-sex interaction associated with multiple sclerosis has been detected. Conclusions. Our results suggest susceptibility of the rs 2348071 heterozygous genotype to multiple sclerosis in Latvians.
\end{abstract}

Keywords: chromosome 14q, proteasomal genes, SNPs, PSMB5, PSMA3, multiple sclerosis.

Introduction. Multiple sclerosis (MS) is the most common, extremely heterogeneous clinically, chronic inflammatory disease of the CNS affecting about 2.5 million people around the world (2500 of them in Latvia), presumably young adults, with onset usually at the second to fourth decade of life and, similarly to other autoimmune diseases, women being affected 3-4 times more frequent than men [1].

About $90 \%$ of MS patients experience the relapsingremitting MS course (RRMS), the majority of these patients enter a secondary progressive course (SPMS) and about $10 \%$ of MS patients show a primary progressive MS form, characterized by the progression of neurological disability from onset [2]. The cause of MS is not clear. The disease develops in genetically susceptible in-

(C) Institute of Molecular Biology and Genetics, NAS of Ukraine, 2014 dividuals with contributions of environmental factors, such as infection, sunlight exposure, vitamin D deficiency $[3,4]$. The MS susceptible loci had been identified in the regions containing genes with immune, co-stimulatory, signal transduction functions and related to vitamin D function [5-10].

Ubiquitin proteasome system (UPS) plays a crucial role in immunity and its disregulation and/or modulation may influence the MS development and progression. The 20S proteasome had been identified as a target of the humoral autoreactive immune response [11] and a major autoantigen in MS patients [12]. The proteolytic activities of proteasomes are reduced in brain tissue of MS patients [13]. The inhibition of proteasomes and lysosomal proteases involved in major histocompability complex II antigen presentation was shown to improve the MS therapeutic effect $[11,14]$. 
Modulation of UPS efficiency could be influenced by polymorphisms in the genes encoding UPS related proteins. The immunoproteasome PSMB9 codon $60 \mathrm{HH}$ variant was observed to have a reduced risk of developing MS in HLA-A*02 + Italian females [15].

Coexistence of autoimmune diseases recently evaluated statistically [16] suggests a possibility of their common origin. In fact, despite generally heterogeneous genetic architecture of the particular disease, some polymorphic loci were shown to be shared by MS and other autoimmune diseases including rheumatoid arthritis [6, 17, 18] and type 1 diabetes mellitus $[19,20]$.

Genetic variations in the 14q11-24 genes encoding proteasomal subunits were implicated previously in susceptibility to autoimmunity, type 2 diabetes mellitus, cardio-vascular disorders, and population adaptation to environment [21, 22]. It appears that there is a large potential for some of these mutations also to be associated with multiple sclerosis.

The aim of the current study was to genotype the rs11543947 and rs2348071 polymorphisms of the PSMB 5 and PSMA3 genes encoding proteasomal proteins on the MS main, subtype and sex specific association in Latvian population.

Materials and methods. Case-control study. The case group consisted of $281 \mathrm{MS}$ patients referred to the Latvian Maritime Medicine Center, Vecmilgravis Hospital. MS patients were diagnosed according to the revised $2010 \mathrm{McDonald}$ criteria [23] and assigned to the RRMS (188 patients) and SPMS (93 patients) groups. Detailed description of the subject groups is given in Table 1. Total control group of 305 samples were represented by the two independent sample sets including the previously characterized [21, 22] first Latvian population study consisting of 191 samples and the second Latvian population study of 114 newly collected samples. Ethnic origin of the subjects was not recorded; all of them represent very mixed inhabitants of Riga, forming some «average» genotype for North-East Europe. The data on the rs 11543947 and rs2348071 allele and genotype frequencies in the first Latvian population sample set were extracted from $[21,22]$ to be compared with the data on genetic diversity obtained for the second Latvian population study and then to be grouped providing a total control group of 305 healthy individuals. All controls were carefully assessed to exclude the diagno-
Table 1

Description of the sample collections

\begin{tabular}{|c|c|c|c|}
\hline $\begin{array}{l}\text { Group } \\
\quad \text { Subgroup }\end{array}$ & Sex & Number & Age $\pm \mathrm{SD}$ (years) \\
\hline \multirow[t]{3}{*}{$\begin{array}{l}\text { Cases } \\
\text { MS }\end{array}$} & Total & 281 & $42.77 \pm 11.10$ \\
\hline & Females & 199 & $43.21 \pm 10.87$ \\
\hline & Males & 82 & $41.51 \pm 11.65$ \\
\hline \multirow[t]{3}{*}{ RRMS } & Total & 188 & $38.80 \pm 9.50$ \\
\hline & Females & 132 & $39.42 \pm 9.47$ \\
\hline & Males & 56 & $37.30 \pm 9.50$ \\
\hline \multirow[t]{3}{*}{ SPMS } & Total & 93 & $50.56 \pm 9.88$ \\
\hline & Females & 67 & $50.61 \pm 9.53$ \\
\hline & Males & 26 & $50.42 \pm 10.92$ \\
\hline \multirow[t]{3}{*}{$\begin{array}{l}\text { Controls } \\
\text { Common }\end{array}$} & Total & 305 & $38.80 \pm 10.54$ \\
\hline & Females & 179 & $38.78 \pm 11.52$ \\
\hline & Males & 126 & $37.22 \pm 9.33$ \\
\hline \multirow[t]{3}{*}{ First population } & Total & 191 & $54.80 \pm 18.60$ \\
\hline & Females & 117 & $56.04 \pm 19.84$ \\
\hline & Males & 74 & $53.56 \pm 17.36$ \\
\hline \multirow[t]{3}{*}{ Second population } & Total & 114 & $21.20 \pm 2.47$ \\
\hline & Females & 62 & $21.52 \pm 3.19$ \\
\hline & Males & 52 & $20.88 \pm 1.29$ \\
\hline
\end{tabular}

sis of any inflammatory disorders. The studies were approved by the Central Medical Ethics Commission of the Republic of Latvia Ministry of Health and informed consent was obtained from all the studies participants.

DNA extraction and genotyping. Genomic DNA was extracted from nucleated blood cells using a kit for the genomic DNA extraction («Fermentas», Lithuania) and from oral swabs using the salting out method [24]. The rs11543947 and rs2348071 genotyping technologies were the same as published previously [21,22] including primer sequences, basic PCR procedure and analyses of amplified and digested products. For quality control, the 16 randomly chosen samples per each marker were genotyped in duplicate in different experiments. The concordance of genotyping was $100 \%$. The genotyping data were verified by direct sequencing of the corresponding DNA fragments in both directions 
using the Applied Biosystems 3130xl Genetic Analyzer. Loci description and nucleotide numbering are given according to the recommended nomenclature system (http://www.genomic.unimelb.edu.au/mdi/mutno men/recs.html). The chromosome 14 GRCh37.p5 assembly (NCBI reference sequence: NC_000014.8) sequence information was used for loci description.

Data analysis. Single locus genotypes and alleles' frequencies were estimated by direct gene counting. The deviation from the Hardy-Weinberg equilibrium (HWE) and differences between case and control groups in allele, genotype and haplotype frequencies were evaluated by $\chi^{2}$ using XLSTAT 2013 software for Windows. The dominant, recessive, over dominant and multiplicative genetic models for every individual locus were designed according to [25] and analysed by using $2 \times 2$ contingency tables. The odds ratio (OR) more than 2 and less than 0.5 was considered to be clinically significant. Stratification was performed by MS courses and sex.

Results and discussion. In both MS and the two Latvian population cohorts, the genotyping call rate was $100 \%$. Both markers were found to be in HWE in controls $\left(c^{2}=2.72 ; p>0.05\right)$. Allele and genotype spectrums and distributions were found to be similar $(\mathrm{P}>0.05)$ for the first (191 samples, [21, 22]) and the second (114 newly collected samples) Latvian population studies for each marker. The data of both population studies were grouped and total control group of 305 samples was used for further analysis. In cases the genotype distribution corresponded to $\operatorname{HWE}\left(\mathrm{c}^{2}=2.72 ; \mathrm{P}>0.05\right)$ for rs 11543947, however a strong deviation from HWE was observed for rs2348071 $\left(\mathrm{c}^{2}=14.14 ; \mathrm{P}<0.01\right)$. Figure illustrates SNPs the genetic diversity in cases and controls.

Depending on the transcript variant, the rs 11543947 locus belongs to the PSMB5 gene exon 1 (c. $70 \mathrm{C}>\mathrm{T}$ ) or intron $1(\mathrm{c} .112+300 \mathrm{C}>\mathrm{T})$. The allele and genotype frequencies of this SNP were found to be similar for cases and controls, RRMS and SPMS cohorts (Figure, $A$ ) as well as for sexes (not shown). Similarly to current data, in Latvians this SNP did not show any association with juvenile idiopathic arthritis [22] and bronchial asthma in children (own unpublished data). However, this locus appears to be susceptible to familial obesity in Latvian children (own unpublished data).

The rs $2348071 \mathrm{SNP}$ is located in the intron 7 of the $P S M A 3$ gene (c. $543+138 \mathrm{G}>\mathrm{A}$ or c. $522+138 \mathrm{G}>\mathrm{A}$

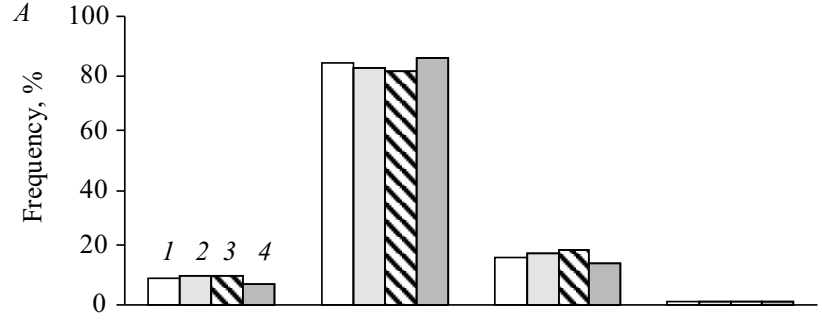

$\mathrm{T}$

$\mathrm{CC}$

CT

TT

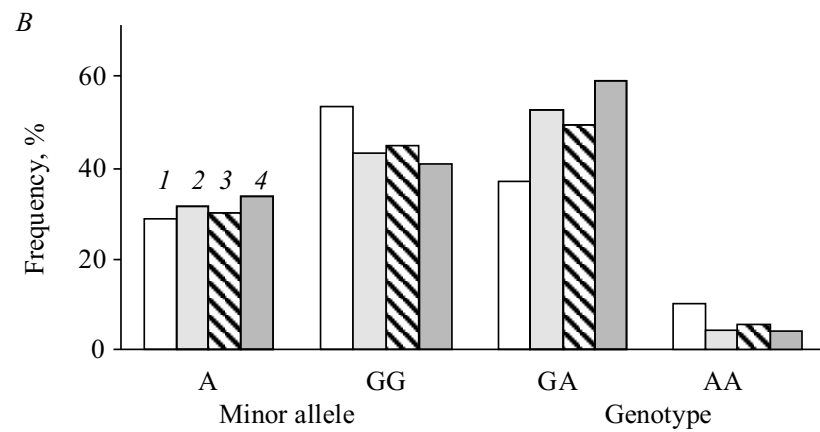

Allele and genotype presentation in MS patients and controls: $A-$ rs11543947; $B$ - rs2348071; ( 1 - control; 2 - MS (multiple sclerosis); 3, 4 - RRMS and SPMS (relapsing remitting and secondary progressive MS course respectively))

depending on the transcript variant) and strongly discriminates Asians having as major an ancestral allele A (about $70 \%$ ) and other ethnics having as major an allele $\mathrm{G}$ (about $70 \%$ ). Transition $\mathrm{A} \rightarrow \mathrm{G}$ happened in Caucasians about 15,000 years ago and was supported by positive selection in Caucasians over the world [21]. The allele frequencies observed in current study were similar for MS patients and controls, however genotype distribution was found to be significantly different (Figure, $B$ ). Both common and rare allele homozygotes appear to be MS protective, however, heterozygous GA genotype showed strong $(\mathrm{p}<0.001)$ MS main effect, and strong and moderate association with the SPMS and RRMS respectively (Table 2).

Previously we have shown $[21,22]$ that nucleotide substitution at the rs 2348071 may significantly change patterns of local targets for many regulatory molecules including proteins of CART, MEF2 and HBPX families known to mediate transcriptional control of neuronal differentiation and nucleo- and cytoplasmic ribonucleoprotein hnRNP A1 implicated in pathogenesis of many neurodegenerative diseases including multiple sclerosis [26-28]. Multiple sclerosis patients were shown to generate antibodies to hnRNP A1 [26]. This splicing signal affecting splicing and post-transcriptional modifi- 
Table 2

Statistical result on the rs2348071 association with multiple sclerosis

\begin{tabular}{|c|c|c|c|c|c|c|}
\hline \multirow{2}{*}{ Genetic model } & Control & MS & RRMS & SPMS & \multirow{2}{*}{$\mathrm{P}$} & \multirow{2}{*}{ OR $[95 \% \mathrm{CI}]$} \\
\hline & $n=305$ & $n=281$ & $n=188$ & $n=93$ & & \\
\hline $\mathrm{GG} v s \mathrm{AA}+\mathrm{GA}$ & 161 vs 144 & 119 vs 162 & 85 vs 103 & 34 vs 59 & $\begin{array}{l}\mathrm{P}_{\mathrm{MS}}<0.05 \\
\mathrm{P}_{\mathrm{SPMS}}<0.01\end{array}$ & $\begin{array}{c}\mathrm{OR}_{\mathrm{MS}}=0.657 \\
{[0.474-0.910]} \\
\mathrm{OR}_{\mathrm{SPMS}}=0.515 \\
{[0.320-0.829]}\end{array}$ \\
\hline $\mathrm{AA} v s \mathrm{GG}+\mathrm{GA}$ & 31 vs 274 & 14 vs 267 & 10 vs 178 & 4 vs 89 & $\begin{array}{l}\mathrm{P}_{\mathrm{MS}}<0.05 \\
\mathrm{P}_{\mathrm{MS}}<0.001\end{array}$ & $\begin{array}{c}\mathrm{OR}_{\mathrm{MS}}=0.463 \\
{[0.243-0.883]} \\
\mathrm{OR}_{\mathrm{MS}}=1.891 \\
{[1.360-2.628]}\end{array}$ \\
\hline $\mathrm{GA} v s \mathrm{GG}+\mathrm{AA}$ & 113 vs 192 & 148 vs 133 & 93 vs 95 & 55 vs 38 & $\begin{array}{l}\mathrm{P}_{\text {RRMS }}<0.01 \\
\mathrm{P}_{\text {SPMS }}<0.001\end{array}$ & $\begin{array}{c}\mathrm{OR}_{\text {RRMS }}=1.663 \\
{[1.152-2.402] ;} \\
\mathrm{OR}_{\text {SPMS }}=2.459 \\
{[1.534-3.943]}\end{array}$ \\
\hline
\end{tabular}

cation of majority of expressed genes in mammals, was shown to interact directly with PSMA3 proteins [29] and may be potentially involved in regulation of the PSMA3 gene expression through the rs2348071 allelespecific targeting. In our previous studies, the rs 2348071 heterozygotes were identified also as risk factor in Latvians for juvenile idiopathic arthritis [22], obesity in children with family history [30] and children bronchial asthma (own unpublished observation). In this study we have tried to analyse separately the groups of RRMS and SPMS patients, although the latter is considered to be the result of progression of the former. It should be mentioned that in some studies [31] the two forms appear to differ genetically. This provided background for the design of the study; in fact in our case the rs2348071 heterozygote genotype was stronger associated with SPMS than with RRMS (Table 2).

We suggest that the rs 2348071 heterozygote genotype is a case of heterozygote disadvantage resulted from the imbalance of the locus functional capacity affecting human health possibly through the modulation and/or deregulation of the PSMA3 gene expression, UPS functionality and network of different genes and proteins involved in pathogenesis of multiple sclerosis and other neurodegenerative and autoimmune diseases.

Conclusions. Our results suggest susceptibility of the rs2348071 heterozygous genotype to multiple sclerosis in Latvians.

Acknowledgements \& Funding. Costs of this work was covered by the European Social Foundation Project No 2013/0043/1DP/1.1.1.2.0/13/APIA/VIAA/002.
Оцінка асоціації поліморфізму генів PSMB5 (rs11543947) і $P S M A 3$ (rs2348071) з розсіяним склерозом 3-поміж жителів Латвії

I. Калниня, Н. Парамонова, Н. Сьяксте, Т. Сьяксте

Резюме

Протеасоми опосередковують виконання функиій багатьох сигнальних білків і факторів транскрипиії, залучених до розвитку розсіяного склерозу. Мета. Оиінити можливу асоиіацію генетичних варіантів генів PSMB5 і PSMA3 зі схильністю до захворювання на розсіяний склероз з-поміж жителів Латвії. Методи. Локуси rs11543947 (РSMB5) і rs2348071 (РSМА3) генотипували у 291 хворого на розсіяний склероз та у 305 здорових індивідів і оиінювали за асоиіаиією із захворюваністю на розсіяний склероз як такий, із підтипами хвороби і пов 'язаною зі статтю асоиіаиією. Рeзультати. Локус rs11543947виявився не пов 'язаним з хворобою, а локус rs 2348071 - асоиійованим з нею. Гетерозиготний генотип ГА локуса rs2348071 тісно асоџійований із захворюванням як таким $(P<0,001$; співвідношення шансів $(C Ш I)=1,891 ; 95 \%$ ДI [1.360-2.628]), помірно асоиійований $(P<0,01 ; C Ш I=1,663 ; 95 \%$ ДI [1,152-2,402]) з ремітуючо-рецидивуючою формою захворювання та сильно $(P<0,001 ; С Ш=2,459 ; 95 \%$ ДІ [1,534-3,943])зі вторинно прогресуючою формою. Пов'язаної з хворобою взаємодії між статтю і генотипом суб 'єкта не відмічено. Висновки. Наші результати вказують на те, що жителі Латвії з гетерозиготним генотипом rs 2348071 схильні до захворювання на розсіяний склероз.

Ключові слова: хромосома 14q, протеасомні гени, однонуклеотидний поліморфізм, PSMB5, PSMA3, розсіяний склероз.

Оценка ассоциации полиморфизма генов PSMB5 (rs11543947) и PSMA3 (rs2348071) с рассеянным склерозом среди жителей Латвии

И. Калныня, Н. Парамонова, Н. Сьяксте, Т. Сьяксте

Резюме

Протеасомы опосредуют выполнение функиий многих сигнальных белков и факторов транскрипиии, вовлеченных в развитие рассеянного склероза. Цель. Оценить возможную ассоциацию генетических вариантов генов PSMB5 и PSMA3 с подверженностью заболеванию рассеянным склерозом среди жителей Латвии. Методы. Локусы rs11543947 (PSMB5) и rs2348071 (PSMA3) генотипи- 
ровали у 291 больного рассеянным склерозом и у 305 здоровых индивидов и оиенивали по ассоичации с заболеваемостью рассеянным склерозом как таковым, подтипами болезни и связанной с полом ассоичиачии. Результаты. Локус rs11543947 оказался не связанным с болезнью, а локус rs 2348071 - ассоциированным с заболеванием. Гетерозиготный генотип ГА локуса rs2348071 тесно ассочиирован с заболеванием как таковым $(P<0,001$; отночение шансов $(О Ш)=1,891,95 \%$ ДИ [1.360-2.628]), умеренно $(P<$ 0,01; ОШ =1,663, $95 \%$ ДИ [1,152-2,402]) - с ремиттирующе-реичдивирующей формой заболевания и сильно $(P<0,001 ;$ ОШ 2,459, $95 \%$ ДИ [1,534-3,943]) - со вторично прогрессирущей формой. Связанного с болезнью взаимодействия между полом и генотипом субъекта не отмечено. Выводы. Наши результаты указывают на подверженность жителей Латвии с гетерозиготным генотипом rs2348071 заболеваемости рассеянным склерозом.

Ключевые слова: хромосома 14q, протеасомные гены, однонуклеотидный полиморфизм, PSMB5, PSMA3, рассеянный склероз.

\section{REFERENCES}

1. Compston A, McDonald I, Noseworth J, Lassmann H, Miller D Smith K, Wekerle H, Confavreux C. McAlpine's multiple sclerosis. Churchill Livingstone, Elsevier, 2005; 926 p.

2. Bellavista E, Santoro A, Galimberti D, Comi C, Luciani F, Mishto $M$. Current understanding on the role of standard and immunoproteasomes in inflammatory/immunological pathways of multiple sclerosis. Autoimmune Dis. 2014;2014:739705.

3. Miller AE. Multiple sclerosis: where will we be in 2020? Mt Sinai J Med. 2011;78(2):268-79.

4. Song GG, Choi SJ, Ji JD, Lee YH. Genome-wide pathway analysis of a genome-wide association study on multiple sclerosis. Mol Biol Rep. 2013;40(3):2557-64.

5. International Multiple Sclerosis Genetics Conssortium (IMSGC). IL12A, MPHOSPH9/CDK2AP1 and RGS1 are novel multiple sclerosis susceptibility loci. Genes Immun. 2010;11(5):397-405.

6. International Multiple Sclerosis Genetics Consortium; Wellcome Trust Case Control Consortium 2, Sawcer S, Hellenthal G, Pirinen $M$, Spencer $C C$, et al. Genetic risk and a primary role for cell-mediated immune mechanisms in multiple sclerosis. Nature. 2011;476(7359):214-9

7. International Multiple Sclerosis Genetics Consortium, Hafler DA, Compston A, Sawcer S, Lander ES, Daly MJ, et al. Risk alleles for multiple sclerosis identified by a genomewide study. $N$ Engl J Med. 2007;357(9):851-62.

8. Australia and New Zealand Multiple Sclerosis Genetics Consortium (ANZgene). Genome-wide association study identifies new multiple sclerosis susceptibility loci on chromosomes 12 and 20. Nat Genet. 2009;41(7):824-8.

9. Kofler DM, Severson CA, Mousissian N, De Jager PL, Hafler DA. The CD6 multiple sclerosis susceptibility allele is associated with alterations in $\mathrm{CD}^{+} \mathrm{T}$ cell proliferation. J Immunol. 2011; 187(6):3286-91.

10. Zhang K, Chang S, Cui S, Guo L, Zhang L, Wang J. ICSN Pathway: identify candidate causal SNPs and pathways from genome-wide association study by one analytical framework. Nucleic Acids Res. 2011;39(Web Server issue):W437-43.

11. Fissolo N, Kraus M, Reich M, Ayturan M, Overkleeft H, Driessen $C$, Weissert $R$. Dual inhibition of proteasomal and lysosomal proteolysis ameliorates autoimmune central nervous system inflammation. Eur J Immunol. 2008;38(9):2401-11.

12. Mayo I, Arribas J, Villoslada P, et al. The proteasome is a major autoantigen in multiple sclerosis. Brain. 2002;125(Pt 12):2658-67.

13. Zheng J, Bizzozero OA. Decreased activity of the $20 \mathrm{~S}$ proteasome in the brain white matter and gray matter of patients with multiple sclerosis. J Neurochem. 2011;117(1):143-53.
14. Minagar $A, M a W$, Zhang $X$, et al. Plasma ubiquitin-proteasome system profile in patients with multiple sclerosis: correlation with clinical features, neuroimaging, and treatment with interferon-beta-1b. Neurol Res. 2012;34(6):611-8.

15. Mishto M, Bellavista E, Ligorio $C$, et al. Immunoproteasome LMP2 $60 \mathrm{HH}$ variant alters MBP epitope generation and reduces the risk to develop multiple sclerosis in Italian female population. PLoS One. 2010;5(2):e9287.

16. Rojas-Villarraga A, Amaya-Amaya J, Rodriguez-Rodriguez A, Mantilla RD, Anaya JM. Introducing polyautoimmunity: secondary autoimmune diseases no longer exist. Autoimmune Dis. 2012;2012:254319.

17. Brand OJ, Gough SC. Immunogenetic mechanisms leading to thyroid autoimmunity: recent advances in identifying susceptibility genes and regions. Curr Genomics. 2011;12(8):526-41.

18. Zoledziewska $M$, Costa $G$, Pitzalis $M$, et al. Variation within the CLEC16A gene shows consistent disease association with both multiple sclerosis and type 1 diabetes in Sardinia. Genes Immun. 2009;10(1):15-7.

19. Maier LM, Lowe CE, Cooper J, et al. IL2RA genetic heterogeneity in multiple sclerosis and type 1 diabetes susceptibility and soluble interleukin-2 receptor production. PLoS Genet. 2009;5 (1):e1000322.

20. Pitzalis $M$, Zavattari $P$, Murru R, et al. Genetic loci linked to type 1 diabetes and multiple sclerosis families in Sardinia. $B M C$ Med Genet. 2008;9:3.

21. Sjakste T, Paramonova N, Shi-Shin Wu L, et al. PSMA6 (rs2277460, rs1048990), PSMC6 (rs2295826, rs2295827) and PSMA3 (rs2348071) genetic diversity in Latvians, Lithuanians and Taiwanese. Meta Gene. 2014; 2:283-98.

22. Sjakste T, Paramonova N, Rumba-Rozenfelde I, Trapina I, Sugoka $O$, Sjakste N. Juvenile Idiopathic Arthritis Subtype- and Sex-specific Associations with Genetic Variants in the PSMA6. PSMC6. PSMA3 Gene Cluster. Pediatr Neonatol. 2014; May 26.pii: S1875-9572(14)00063-1.10.1016/j.pedneo.2014.01.007.

23. Polman CH, Reingold SC, Banwell B, et al. Diagnostic criteria for multiple sclerosis: 2010 revisions to the McDonald criteria. Ann Neurol. 2011;69(2):292-302.

24. Miller SA, Dykes DD, Polesky HF. A simple salting out procedure for extracting DNA from human nucleated cells. Nucleic Acids Res. 1988;16(3):1215.

25. Lewis $C M$. Genetic association studies: design, analysis and interpretation. Brief Bioinform. 2002;3(2):146-53.

26. Johnson DA, Amirahmadi S, Ward C, Fabry Z, Johnson JA. The absence of the pro-antioxidant transcription factor Nrf2 exacerbates experimental autoimmune encephalomyelitis. Toxicol Sci. 2010;114(2):237-46.

27. Lee $S, X u$ L, Shin Y, Gardner L, Hartzes A, Dohan FC, Raine C, Homayouni $R$, Levin $M C$. A potential link between autoimmunity and neurodegeneration in immune-mediated neurological disease. J Neuroimmunol. 2011;235(1-2):56-69.

28. Bekenstein U, Soreq H. Heterogeneous nuclear ribonucleoprotein $\mathrm{A} 1$ in health and neurodegenerative disease: from structural insights to post-transcriptional regulatory roles. Mol Cell Neurosci. 2013;56:436-46.

29. Fedorova OA, Moiseeva TN, Nikiforov AA, et al. Proteomic analysis of the $20 \mathrm{~S}$ proteasome (PSMA3)-interacting proteins reveals a functional link between the proteasome and mRNA metabolism. Biochem Biophys Res Commun. 2011;416(3-4):258-65.

30. Kupca S, Sjakste T, Paramonova N, et al. Association of obesity with proteasomal gene polymorphisms in children. J Obes. 2013; 2013:638154.

31. Arli B, Irkec C, Menevse S, Yilmaz A, Alp E. Fractalkine gene receptor polymorphism in patients with multiple sclerosis. Int $J$ Neurosci. 2013;123(1):31-7.

Received 04.05.14 